\title{
PENGERINGAN BUSA TERHADAP AMPAS SEDUHAN TEH MENURUT MODEL KINETIKA LEWIS, PAGE DAN HENDERSON-PABIS
}

\author{
Indah Hartati", Maharani Kusumaningrum, Laeli Kurniasari \\ Jurusan Teknik Kimia, Fakultas Teknik, Universitas Wahid Hasyim Semarang \\ Jalan Menoreh Tengah X no 22 Semarang \\ Email:hartatiprasetyo@gmail.com
}

\begin{abstract}
Abstrak
Ampas seduhan teh dinyatakan memiliki kandungan serat kasar, selulosa, lignin dan berbagai macam mineral seperti tembaga, magnesium dan kalsium. Proses pengeringan serbuk ampas seduhan teh dapat mendorong pemanfaatan dan penggunaan lebih lanjut terhadap ampas teh. Dalam penelitian ini, pengeringan ampas seduhan teh dilakukan menggunakan metode pengeringan busa. Penelitian ini bertujuan untuk mengkaji kinetika pengeringan busa terhadap ampas seduhan teh menggunakan model kinetika Lewis, Page dan Henderson-Pabis. Proses pengeringan busa terhadap ampas seduhan teh dilakukan dengan memvariasi konsentrasi agen pembusa (maltodekstrin) 10\%-20\% serta dengan menambahkan putih telur sebesar $15 \%$ dan aliran udara panas bersuhu $80^{\circ} \mathrm{C}$. Hasil penelitian menunjukkan bila dibandingkan dengan model kinetika Lewis maupun Henderson-Pabis, maka model Page memiliki kesesuaian yang lebih tinggi terhadap data eksperimen proses pengeringan busa terhadap ampas teh. Nilai kontanta kecepatan pengeringan $(k)$ semakin meningkat seiring dengan peningkatan kadar maltodekstrin yang ditambahkan. Nilai konstanta kecepatan pengeringan yang terbesar pada model Page yakni sebesar 0,0593/menit diperoleh pada proses pengeringan busa terhadap ampas teh yang dilakukan dengan menambahkan putih telur sebesar $15 \%$, aliran udara panas bersuhu $80^{\circ} \mathrm{C}$ dan penambahan maltodekstrin sebesar $20 \%$.
\end{abstract}

Kata Kunci: ampas teh, henderson-pabi, lewis, page, pengeringan busa

\section{PENDAHULUAN}

Proses pengeringan merupakan salah satu proses yang banyak diaplikasikan dalam proses pengolahan pangan. Proses pengeringan dapat dibagi menjadi 3 metode yakni pengeringan konvektif, pengeringan konduktif dan pengeringan radiatif (Bennamoun dan Li; 2018). Salah satu proses pengeringan konvektif yang telah banyak dikaji dan diaplikasikan dalam proses pengolahan pangan adalah proses pengeringan busa (foam mat drying). Teknik pengeringan busa melibatkan pencampuran material yang akan dikeringkan dengan zat penstabil dan atau agen pembusa untuk menghasilkan busa yang stabil dan dikeringkan dengan udara panas pada suhu yang berkisar antara $50-80^{\circ} \mathrm{C}$ (Maria de Carvalho dkk., 2017). Agen pembusa yang dapat digunakan dalam proses pengeringan busa diantaranya adalah putih telur, isolat protein kedelai, dan protein kedelai termodifikasi (Thuwapanichayanan dkk., 2008); CMC (Lobo dkk., 2017); maltodekstrin (Maria de Carvalho dkk., 2017); serta ovalbumin (Dehghannya dkk., 2018).

Apabila dibandingkan dengan teknik pengeringan yang lain, pengeringan busa dinyatakan memiliki beberapa kelebihan seperti proses pengeringan yang lebih cepat dan menghasilkan produk dengan kualitas yang lebih baik. Hal tersebut disebabkan struktur busa yang berpori dan memiliki luas area yang yang lebih besar akan meningkatkan perpindahan massa selama pross dehidrasi (Lobo dkk., 2017). Menimbang berbagai kelebihan dari proses pengeringan busa, maka berbagai kajian 
mengenai aplikasi pengeringan busa telah dilakukan oleh beberapa peneliti. Pengeringan busa telah diaplikasikan dalam proses pengeringan jus apel (Kudra dan Ratti; 2006); pulp manga Tommy Atkins (Lobo dkk.,2016); jus buah Jambolan (Syzygium cumini L.) (Maria de Carvalho dkk., 2017), dan jus jeruk lemon (Dehghannya dkk., 2018).

Teknik pengeringan busa diduga juga tepat untuk diaplikasikan dalam proses pengeringan serbuk ampas seduhan teh. Ampas seduhan teh merupakan produk samping industri pembuatan minuman teh dalam kemasan serta dapat berasal dari limbah domestik rumah tangga. Industri pengolahan teh berpotensi menghasilkan limbah ampas seduhan teh hingga mencapai 12 ton/bulan. Limbah ampas teh dinyatakan mengandung serat kasar, selulosa, lignin dan berbagai macam mineral seperti karbon organik, tembaga $(\mathrm{Cu}) 20 \%$, magnesium (Mg) 10\%, dan kalsium 13\%. Selain dinyatakan memiliki berbagai kandungan mineral dan serat, Farhoosh dkk (2007) menyatakan jika ampas teh memiliki aktivitas antioksidan yang tinggi. Lebih lanjut, hingga kini belum ditemukan kajian mengenai kinetika pengeringan busa terhadap ampas seduhan teh. Oleh karenanya dalam publikasi ilmiah ini disajikan kajian kinetika pengeringan busa terhadap ampas seduhan teh menggunakan model kinetika pengeringan Lewis, Page dan HendersonPabis.

\section{METODOLOGI PENELITIAN \\ Bahan}

Bahan yang digunakan pada penelitian ini adalah ampas teh yang didapatkan dari limbah rumah tangga, maltodekstrin, putih telur dan aquadest.

\section{Proses pengeringan busa}

Proses pengeringan ampas seduhan teh menggunakan metode pengeringan busa dilakukan menurut langkah-langkah sebagaimana tersaji pada Gambar 1. Sampel dianalisa kadar airnya setiap 10 menit dengan menggunakan metode gravimetri.

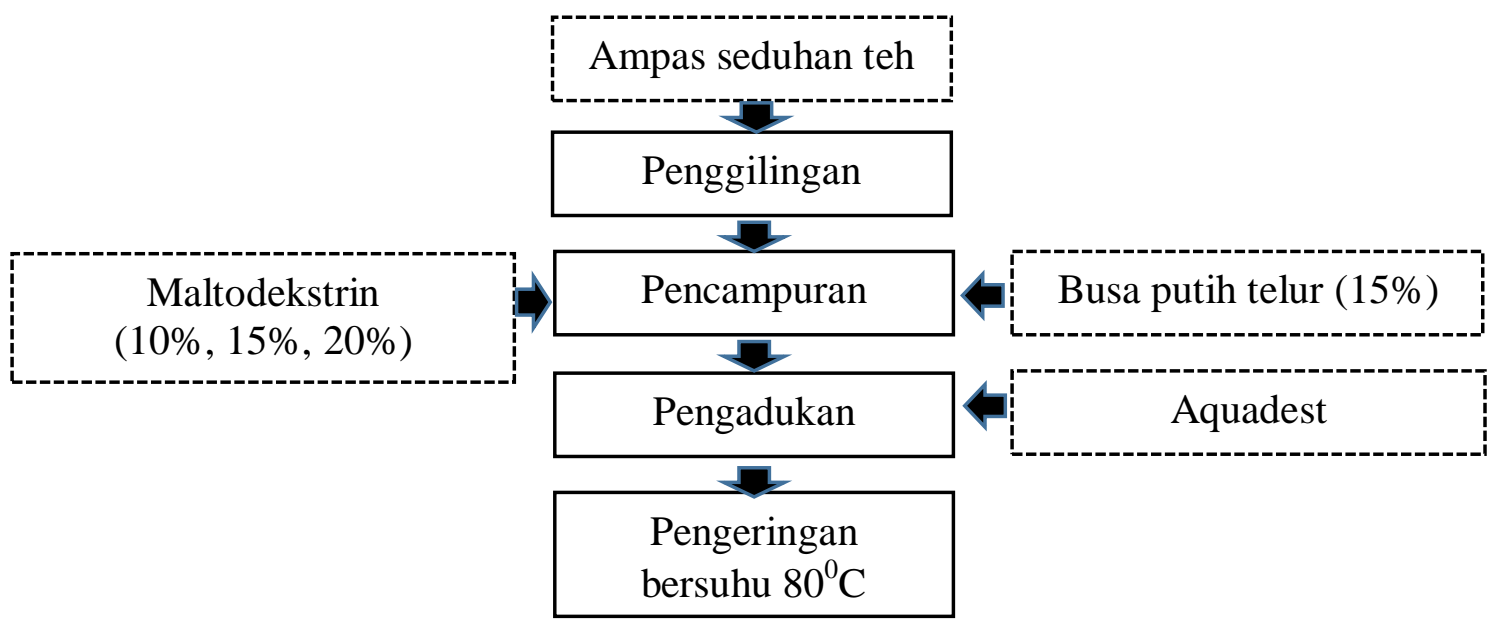

Gambar 1. Skema pengeringan busa ampas seduhan teh

\section{HASIL DAN PEMBAHASAN}

Proses pengeringan busa terhadap ampas seduhan teh dilakukan dengan memvariasi kadar maltodekstrin yang ditambahkan kedalam formulasi busa. Variasi kadar maltodektrin yang 
ditambahkan adalah sebesar $10 \%, 15 \%$ dan 20\%. Data penurunan kadar air pada serbuk ampas seduhan teh yang dikeringkan menggunakan metode pengeringan busa digunakan untuk menghitung MR (moisture ratio) menurut persamaan 1. Moisture ratio merupakan ekspresi bilangan tak berdimensi dan merupakan fungsi waktu.

$$
M R=\frac{M_{\mathrm{t}}-M_{e}}{M_{\mathrm{o}}-M_{e}}
$$

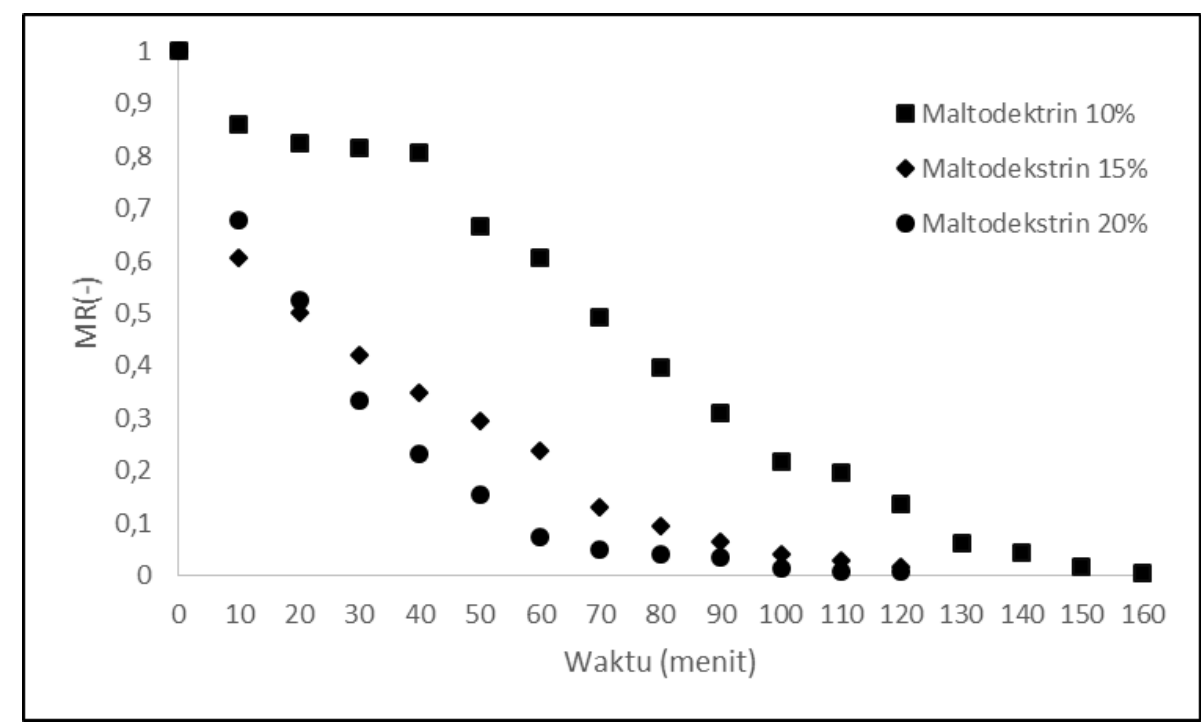

\section{Gambar 2. Mositure ratio dari pengeringan busa ampas seduhan teh yang dilakukan dengan penambahan putih telur $15 \%$ dan maltodekstrin $\mathbf{1 0 - 2 0 \%}$}

Gambar 2 memperlihatkan bahwa nilai moisture ratio yang rendah mampu diperoleh dalam waktu yang lebih singkat untuk proses pengeringan busa yang dilakukan dengan penambahan maltodekstrin yang tinggi. Selanjutnya prosedur fitting kurva (curve fitting) dilakukan terhadap model kinetika pengeringan yang umum digunakan untuk mendeskripsikan proses pengeringan. Model kinetika yang dikaji adalah model Lewis, Henderson-Pabis dan Page. Model kinetika pengeringan menurut Lewis dinyatakan menurut persamaan 2. Ahvad dan Marchetti (2016) menyatakan bahwa dimana $M_{0}$ adalah kadar air awal, $M_{t}$ adalah kadar air pada t tertentu, dan $M_{e}$ adalah kadar air pada kondisi setimbang. Data $\mathrm{MR}_{\text {eksperimen }}$ dari proses pengeringan ampas seduhan teh yang dikeringkan menggunakan metode pengeringan busa disajikan pada Gambar 2. 


$$
M R=a \cdot e k s p(-k t)
$$

Model ketiga yang digunakan untuk mengkaji kinetika pengeringan adalah model Page (Persamaan 4). Model Page diajukan guna memodifiksi model kinetika Lewis dengan memasukkan koefisien baru yang mempengaruhi waktu.

$$
M R=e k s p\left(-k t^{N}\right)
$$

Evaluasi ketepatan model dilakukan berdasarkan nilai parameter SSE.

$$
S S E=\left(M R_{e k s p}-M R_{\text {hit }}\right)^{2}
$$

Moisture ratio hasil perhitungan menggunakan model Lewis, HendersonPabis dan Page disajikan pada Gambar 3-5.

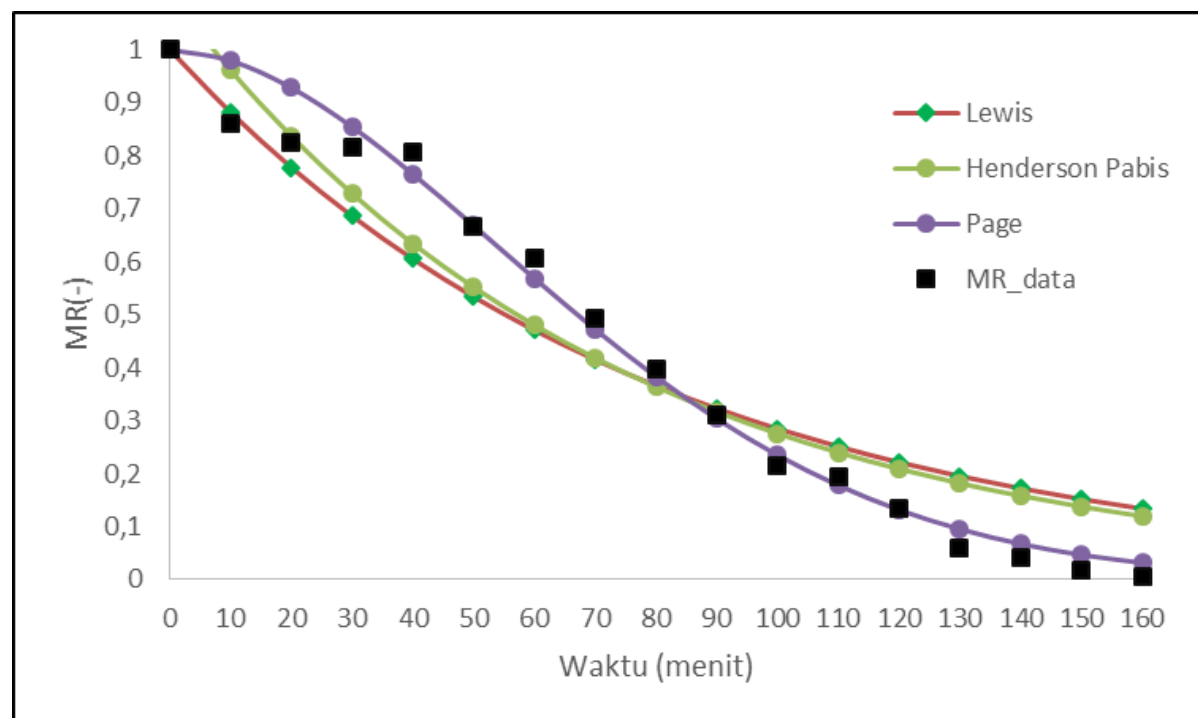

Gambar 3. Komparasi moisture ratio hasil eksperimen dengan moisture rasio hasil perhitungan berdasar model kinetika Lewis, Henderson-Pabis dan Page untuk pengeringan busa ampas seduhan teh yang dilakukan dengan penambahan putih telur $15 \%$ dan maltodekstrin $10 \%$ 


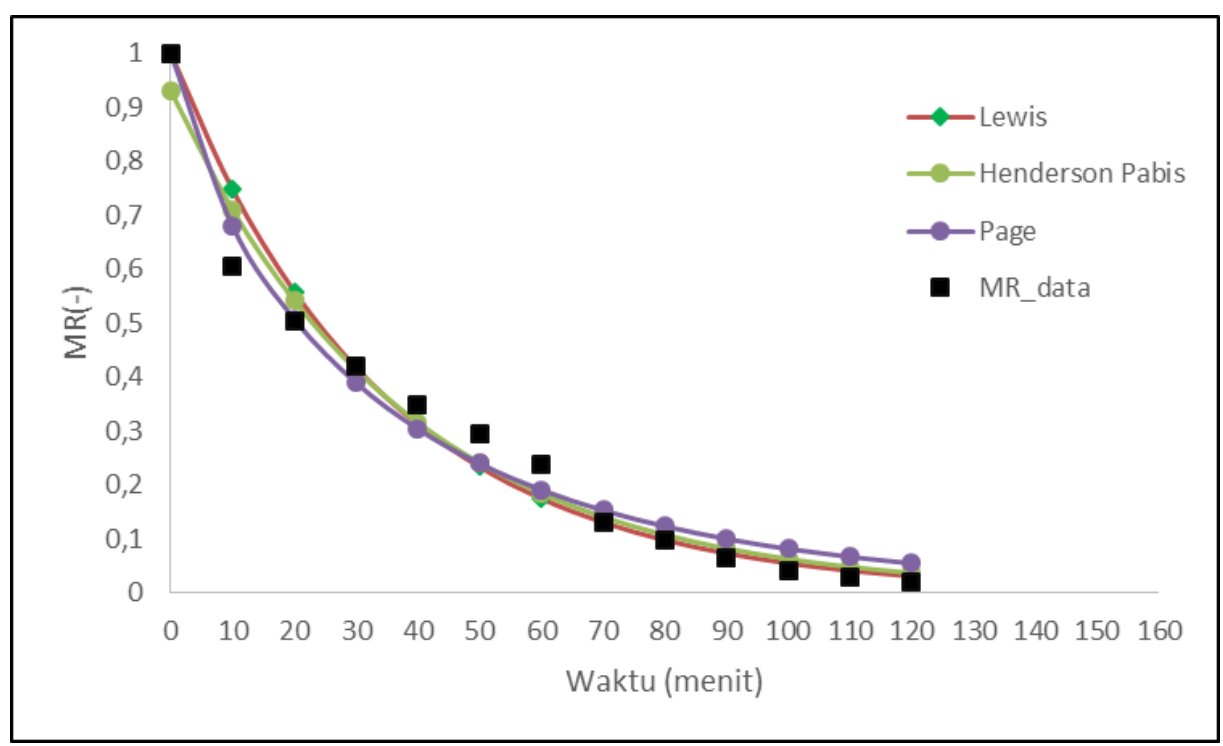

Gambar 4. Komparasi moisture ratio hasil eksperimen dengan moisture rasio hasil perhitungan berdasar model kinetika Lewis, Henderson-Pabis dan Page untuk pengeringan busa ampas seduhan teh yang dilakukan dengan penambahan putih telur $15 \%$ dan maltodekstrin $15 \%$

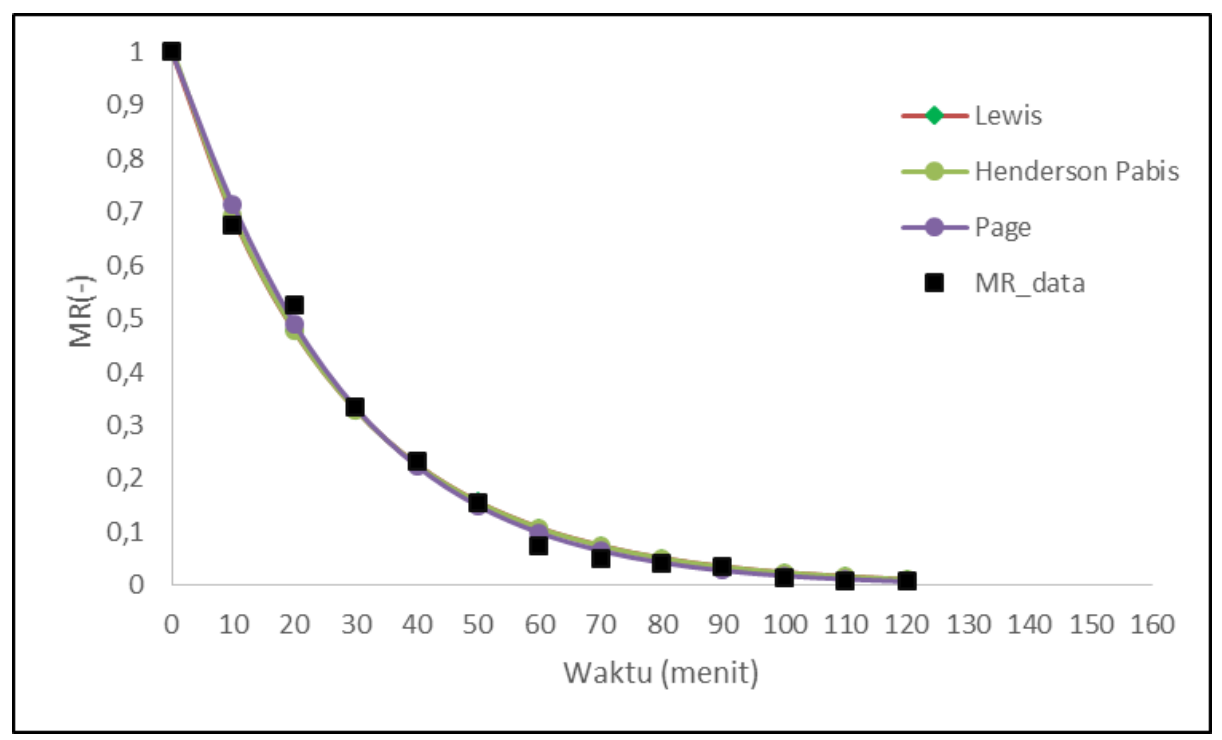

Gambar 5. Komparasi moisture ratio hasil eksperimen dengan moisture rasio hasil perhitungan berdasar model kinetika Lewis, Henderson-Pabis dan Page untuk pengeringan busa ampas seduhan teh yang dilakukan dengan penambahan putih telur 15\% dan maltodekstrin $20 \%$

Berdasarkan hasil perhitungan moisture ratio menggunakan model kinetika Lewis, Henderson-Pabis dan Page dapat diketahui bahwa model Page memiliki kesesuaian yang lebih tinggi bila dibandingkan dengan model kinetika Lewis maupun Henderson-Pabis (Gambar 3-5). Hal tersebut juga didukung oleh nilai SSE dari model Page yang lebih rendah bila dibandingkan dengan SSE model kinetika Lewis maupun Henderson-Pabis 
(Tabel 1). Nilai SSE untuk model Lewis yang divalidasi menggunakan data percobaan proses pengeringan dengan penambahan maltodekstrin sebesar $10 \%$ adalah yang tertinggi, diikuti dengan model HendersonPabis, dan yang terendah adalah nilai SSE untuk model Page, dinama nilai SSE nya secara berturut turut adalah sebesar 0,1879; 0,1609 dan 0,0344. Profil yang sama ditunjukkan untuk proses pengeringan dengan penambahan maltodekstrin sebesar 15\% dan 20\%. Ahvad dan Marchetti (2016) menyatakan bahwa model Page memiliki kesesuaian yang baik saat digunakan untuk mendeskripsikan proses pengeringan beberapa produk pertanian seperti daun salam, kacang pistacio dan rapeseed. Kajian terkait kinetika pengeringan busa yang menunjukkan hasil serupa yakni kesesuaian data eksperimen dengan model Page dinyatakan oleh Guimaraes dkk. (2016). Guimaraes dkk. (2016) mengkaji kinetika proses pengeringan busa terhadap jus mangga menggunakan model Page, Henderson, henderson-Pabis, Logaritmik dan model TwoTerm Exponential. Proses pembusaan dilakukan dengan menambahkan $1 \%$ Emustab® dan $1 \%$ Super Liga Neutra®, dan proses pembusaan dilakukan selama 20 menit. Aliran udara panas yang digunakan bersuhu $50-70^{\circ} \mathrm{C}$ dan ketebalan lapisan busa divariasi antara 0,5-1,5 cm. Hasil penelitian mereka menunjukkan jika Model Page adalah model yang memberikan kesesuaian terbaik bagi data eksperimental proses pengeringan busa jus manga.

Tabel 1. Nilai parameter kinetika pengeringan busa berdasar model Lewis, HendersonPabis dan Page

\begin{tabular}{cccccc}
\hline Model Kinetika & $\begin{array}{c}\text { Konsentrasi } \\
\text { Pengeringan }\end{array}$ & \multicolumn{3}{c}{ Parameter } & SSE \\
\cline { 3 - 4 } & $\begin{array}{c}\text { maltodekstrin } \\
(\%)\end{array}$ & $\mathrm{k}$ & $\mathrm{a}$ & $\mathrm{N}$ & \\
\hline Lewis & 10 & 0,0126 & & & 0,1879 \\
& 15 & 0,0291 & & & 0,0331 \\
& 20 & 0,0370 & & & 0,0048 \\
Henderson-Pabis & 10 & 0,0139 & 1,1046 & & 0,1609 \\
& 15 & 0,0270 & 0,9302 & & 0,0261 \\
& 20 & 0,0373 & 1,0073 & & 0,0048 \\
Page & 10 & 0,0003 & & 1,8439 & 0,0344 \\
& 15 & 0,0593 & & 0,8137 & 0,0207 \\
& 20 & 0,0285 & & 1,0738 & 0,0037 \\
\hline
\end{tabular}

Lebih lanjut, Tabel 1 menunjukkan jika nilai kontanta kecepatan pengeringan (k) semakin meningkat seiring dengan peningkatan kadar maltodekstrin yang ditambahkan. Nilai k yang diperoleh dari proses pemodelan menggunakan model kinetika Lewis dan Henderson-Pabis menunjukkan jika nilai $\mathrm{k}$ semakin besar seiring dengan meningkatnya kadar maltodekstrin yang ditambahkan. Nilai k 
pada model Lewis berkisar antara 0,01260,0370. Sementara nilai $\mathrm{k}$ pada model Henderson-Pabis berkisar antara 0,01390,0373. Hal ini diduga disebabkan oleh karakteristik maltodekstrin yang bersifat higroskopis. Maltodekstrin mampu menyerap air sehingga seiring dengan penambahan maltodektrin maka semakin banyak air yang dapat diserap dan berakibat mempercepat proses pengeringan.

Nilai k yang diperoleh dari proses pemodelan menggunakan model kinetika Page juga semakin meningkat untuk proses pengeringan yang dilakukan dengan penambahan maltodektrin sebesar 10 dan $15 \%$. Namun demikian nilai k untuk proses pengeringan yang dilakukan dengan penambahan maltodektrin sebesar $20 \%$ lebih rendah dibandingkan nilai $\mathrm{k}$ untuk proses pengeringan yang dilakukan dengan penambahan maltodektrin sebesar $15 \%$. Nilai konstanta kecepatan pengeringan yang terbesar pada model Page yakni sebesar 0,0593/menit diperoleh pada proses pengeringan busa terhadap ampas teh yang dilakukan dengan penambahan maltodekstrin sebesar $20 \%$.

\section{KESIMPULAN}

Hasil penelitian menunjukkan bila dibandingkan dengan model kinetika Lewis maupun Henderson-Pabis, maka model Page memiliki kesesuaian yang lebih tinggi terhadap data eksperimen proses pengeringan busa terhadap ampas teh. Nilai kontanta kecepatan pengeringan (k) semakin meningkat seiring dengan peningkatan kadar maltodekstrin yang ditambahkan. Nilai konstanta kecepatan pengeringan yang terbesar pada model Page yakni sebesar 0,0593/menit diperoleh pada proses pengeringan busa terhadap ampas teh yang dilakukan dengan penambahan maltodekstrin sebesar $20 \%$.

\section{DAFTAR PUSTAKA}

Ahvad MR., Marchetti JM., 2016, Mathematical Modelling of the Drying Kinetics of Hass Avocado Seeds. Industria 1 Crops and Products. 91.76-87

Bennamoun L., Li J.,2018, Drying Process of Food: Fundamental Aspects and Mathematical Modelling. Natural and Artificia Flavoring Agents and Food Dyes. Elsevier Inc

Dehghannya J., Pourahmad M., Ghanbarzadeh B., Ghaffari H., 2018, Influence of Foam Thickness on Production of Lime Juice Powder during Foam Mat Drying: Experimental and Numerical Investigation. Powder Technology. 328.

Farhoosh R., Golmovahhed GA., odaparast MHH., 2007, Antioxidant Activity of Various Extract of Old Tea Leaves and Black Tea Wastes. Food Chemistry. 100, 231-236

Guimaraes MKA., de Figueiredo RMF., de Melo Queiroz AJ., 2016, Foam Mat Drying Kinetics of Keitt Mango Pulp. Rev. Caatinga, Mossoró, v. 30, n. 1 , p. $172-180$

Kudra T., Ratti C., 2006, Foam mat Drying: Energy and Cost Analysis. Canadian Biosystem Engineering. 48.

Lobo FA., Nascimento MA., Domingues JR., Falcao DQ., Hernanz D., Heredia FJ., de Lima Araujo KG., 2017,. Foam Mat Drying of Tommy Atkins Mango: Effect of Air Temperature and Concentration of Soy Lecithin and Carboxymethylcellulose on Phenolic Composition, Manginerin, and Antioxidant Capacity. Food Chemistry. 221 
Maria de Carvalho TIM., Nogueira TYK., Mauro MA., Gomez-Alonzo S., Gomez E., da Sila R., HermosinGutierrez I., Lago-Vanzela ES., 2017, Dehydration of Jambolan Juice During Foam Mat Drying: Quantitative and Qualitative Changes of the Phenolic Compound. Food Research International. 102

Thuwapanichayanan R., Prachayawarakorn S., Soponronnarit S., 2008, Drying Characteristics and Quality of Banana Foam Mat. Journal of Food Engineering. 86, 573-583 